\title{
Detecting anthropogenic carbon dioxide uptake and ocean acidification in the North Atlantic Ocean
}

\author{
N. R. Bates ${ }^{1}$, M. H. P. Best ${ }^{1}$, K. Neely ${ }^{1}$, R. Garley ${ }^{1}$, A. G. Dickson ${ }^{2}$, and R. J. Johnson ${ }^{1}$ \\ ${ }^{1}$ Bermuda Institute of Ocean Sciences, Ferry Reach, Bermuda \\ ${ }^{2}$ Scripps Institution of Oceanography, University of California San Diego, La Jolla, California, USA
}

Correspondence to: N. R. Bates (nick.bates@bios.edu)

Received: 14 December 2011 - Published in Biogeosciences Discuss.: 23 January 2012

Revised: 1 June 2012 - Accepted: 8 June 2012 - Published: 11 July 2012

\begin{abstract}
Fossil fuel use, cement manufacture and land-use changes are the primary sources of anthropogenic carbon dioxide $\left(\mathrm{CO}_{2}\right)$ to the atmosphere, with the ocean absorbing approximately $30 \%$ (Sabine et al., 2004). Ocean uptake and chemical equilibration of anthropogenic $\mathrm{CO}_{2}$ with seawater results in a gradual reduction in seawater $\mathrm{pH}$ and saturation states $(\Omega)$ for calcium carbonate $\left(\mathrm{CaCO}_{3}\right)$ minerals in a process termed ocean acidification. Assessing the present and future impact of ocean acidification on marine ecosystems requires detection of the multi-decadal rate of change across ocean basins and at ocean time-series sites. Here, we show the longest continuous record of ocean $\mathrm{CO}_{2}$ changes and ocean acidification in the North Atlantic subtropical gyre near Bermuda from 1983-2011. Dissolved inorganic carbon (DIC) and partial pressure of $\mathrm{CO}_{2}\left(p \mathrm{CO}_{2}\right)$ increased in surface seawater by $\sim 40 \mu \mathrm{mol} \mathrm{kg}{ }^{-1}$ and $\sim 50 \mu \mathrm{atm}(\sim 20 \%)$, respectively. Increasing Revelle factor $(\beta)$ values imply that the capacity of North Atlantic surface waters to absorb $\mathrm{CO}_{2}$ has also diminished. As indicators of ocean acidification, seawater $\mathrm{pH}$ decreased by $\sim 0.05\left(0.0017 \mathrm{yr}^{-1}\right)$ and $\Omega$ values by $\sim 7-8 \%$. Such data provide critically needed multi-decadal information for assessing the North Atlantic Ocean $\mathrm{CO}_{2}$ sink and the $\mathrm{pH}$ changes that determine marine ecosystem responses to ocean acidification.
\end{abstract}

\section{Introduction}

The emissions of anthropogenic $\mathrm{CO}_{2}$ to the atmosphere due to fossil fuel use, cement manufacture and land-use changes (Houghton, 2008) have increased rapidly over the last decade (Friedlingstein et al., 2010). While anthropogenic $\mathrm{CO}_{2}$ accu- mulates in the atmosphere, it is also taken up by the terrestrial biosphere and oceans. The annual global ocean uptake is estimated at $\sim 1.4$ to $2.5 \mathrm{Pg} \mathrm{C} \mathrm{yr}^{-1}$ (e.g., Takahashi et al., 2002; Manning and Keeling, 2006; Takahashi et al. 2009; McKinley et al., 2011; $\mathrm{Pg}=10^{15} \mathrm{~g}$ ), with annual rates of $\mathrm{CO}_{2}$ uptake increasing with time (Le Quéré et al., 2009). The cumulative total global ocean uptake of anthropogenic $\mathrm{CO}_{2}$ since pre-industrial times is estimated at $\sim 120-140$ Pg C (Sabine et al., 2004; Khatiwala et al., 2009). Ocean uptake of anthropogenic $\mathrm{CO}_{2}$ and seawater chemistry changes such as reduction in seawater $\mathrm{pH}$ and saturation states for calcium carbonate $\left(\mathrm{CaCO}_{3}\right)$ minerals such as calcite $\left(\Omega_{\text {calcite }}\right)$ and aragonite $\left(\Omega_{\text {aragonite }}\right)$ is termed ocean acidification (e.g., Calderia and Wickett, 2003, 2005; Orr et al., 2005; Doney et al., 2009; Feely et al., 2009), and has likely problematic consequences for marine organisms and ecosystems that are, as yet, poorly understood.

Assessments of rates of ocean $\mathrm{CO}_{2}$ uptake over multidecadal timeperiods, changes in the capacity of the ocean to absorb $\mathrm{CO}_{2}$ and ocean acidification impacts are important for predicting future climate change and marine ecosystem responses (e.g., Fabry et al., 2009). These ocean carbon cycle and ocean acidification data provide critically needed observational tests of global coupled ocean-atmosphere models and allow attribution of changes to both anthropogenic and natural causes (e.g., Le Quéré et al., 2010). Repeat hydrographic sections provide a means of quantifying basinwide ocean uptake of anthropogenic $\mathrm{CO}_{2}$ (e.g., Friis et al., 2005; Brown et al., 2010; Wanninkhof et al., 2010). Alternatively, higher frequency observations of the changes in seawater chemistry due to uptake of anthropogenic $\mathrm{CO}_{2}$ have been collected at a few ocean time-series near various islands, 
including near Bermuda (Bates, 2001, 2007; Bates and Peters, 2007), Hawaii (e.g., Dore et al., 2003; Brix et al., 2004; Dore et al. 2009), the Canary Islands (Santana-Casiano et al., 2007; Gonzalez-Davila et al., 2010) and Iceland (Olafsson et al., 2010). Here, we examine direct observations of the seawater carbonate chemistry changes resulting from ocean uptake of $\mathrm{CO}_{2}$ over the last 30 years in the subtropical gyre of the North Atlantic Ocean near Bermuda from 1983-2011. Seawater samples were collected from two time-series sites near Bermuda (i.e., Bermuda Atlantic Time-series Study; BATS; $31^{\circ} 40^{\prime} \mathrm{N}, 64^{\circ} 10^{\prime} \mathrm{W}$ (Michaels and Knap, 1998; Steinberg et al., 2001); and Hydrostation S, $32^{\circ} 10^{\prime} \mathrm{N}, 64^{\circ} 30^{\prime} \mathrm{W}$; Keeling, 1993). Samples for dissolved inorganic carbon (DIC and total alkalinity (TA) were analysed (Bates et al., 1996a; Dickson et al., 2007), multi-decadal checks on accuracy of data are made and computations of other components of the seawater carbonate system computed (Robbins et al., 2010). These data provide directly observed indicators of ocean acidification and include $\mathrm{pH}$, carbonate ion concentration $\left(\left[\mathrm{CO}_{3}^{2-}\right]\right)$ and the saturation state for calcium carbonate $\left(\mathrm{CaCO}_{3}\right)$ minerals. Finally, these data are combined with a few earlier measurements in the North Atlantic Ocean (from the Geochemical Ocean Section Study, GEOSECS, Kroopnick et al., 1972; and Transient Tracers in the Ocean, TTO projects; Brewer et al., 1985; data corrected by Tanhua and Wallace, 2005) extending these trends over the past 40 years.

\section{Methods and materials}

\subsection{Seawater carbonate chemistry sampling at BATS}

A time-series of observations of seawater carbonate chemistry observations in the upper ocean have been collected in the subtropical gyre of the North Atlantic Ocean near Bermuda since 1983 at the Bermuda Atlantic Time-series Study (BATS) and Hydrostation S sites (Bates, 2007; Bates and Peters, 2007). The combined ocean time-series data represent monthly water column sampling for DIC and total alkalinity (TA) at BATS with analysis of samples at the Bermuda Institute of Ocean Sciences (BIOS) using highly precise and accurate coulometric and potentiometric techniques, respectively (Bates et al., 1996a,b; Bates, 2001). Additional surface samples were collected at Hydrostation $S$ and analysed for DIC and TA using manometric and potentiometric methods, respectively, at Scripps Institution of Oceanography (Keeling, 1993). Here, DIC is defined as (Dickson et al., 2007):

$\mathrm{DIC}=\left[\mathrm{CO}_{2}^{*}\right]+\left[\mathrm{HCO}_{3}^{-}\right]+\left[\mathrm{CO}_{3}^{2-}\right]$

where $\left[\mathrm{CO}_{2} *\right]$ represents the concentration of all unionized carbon dioxide, whether present as $\mathrm{H}_{2} \mathrm{CO}_{3}$ or as $\mathrm{CO}_{2}$. The total alkalinity of seawater (TA) is defined as:

$$
\begin{aligned}
\mathrm{TA}= & {\left[\mathrm{HCO}_{3}^{-}\right]+2\left[\mathrm{CO}_{3}^{2-}\right]+\left[\mathrm{B}(\mathrm{OH})_{4}^{-}\right]+\left[\mathrm{OH}^{-}\right] } \\
& +\left[\mathrm{HPO}_{4}^{2}-\right]+2\left[\mathrm{PO}_{4}^{3-}\right]+ \\
& {\left[\mathrm{SiO}(\mathrm{OH})_{3}^{-}\right]+\left[\mathrm{HS}^{-}\right]+\left[\mathrm{NH}_{3}\right]+\ldots-\left[\mathrm{H}^{+}\right] } \\
& -\left[\mathrm{HSO}_{4}^{-}\right]-[\mathrm{HF}]-\left[\mathrm{H}_{3} \mathrm{PO}_{4}\right]-\ldots
\end{aligned}
$$

where $\left[\mathrm{HCO}_{3}^{-}\right]+2\left[\mathrm{CO}_{3}^{2-}\right]+\mathrm{B}(\mathrm{OH})_{4}^{-}$are the principal components of seawater TA (Dickson et al., 2007).

\subsection{Sampling frequency at BATS}

The sampling frequency of the combined dataset from Hydrostation $\mathrm{S}$ and BATS was not uniform in time. In the 1980s, samples were collected 9-12 times a year, while since 1992, sampling increased to 14-15 times a year (Fig. 1). The increase in sampling since the middle 1990s was due to supplemental BATS bloom cruises (1 to 4 in number) conducted during the January to April period in addition to BATS core cruises. The increase in sampling frequency over time weights the time-series to springtime when determining non-seasonally aliased trends.

\subsection{Sampling methods}

At Hydrostation S, samples were collected into were collected into 1 litre Pyrex bottles with a change to $500 \mathrm{ml}$ bottles in the early 1990's, sealed, sealed with ground glass stoppers and then shipped to Scripps Institution of Oceanography (SIO) for analysis (Keeling, 1993; Brix et al., 2004). Storage time for samples before analysis ranged from a few months to several years. Similar sampling protocols were established at BIOS for sampling at the BATS (Bates et al., 1996a,b; Bates, $2001)$ but in the early 2000s, smaller Pyrex bottles $(\sim 350 \mathrm{ml})$ were used. Samples were typically analysed within a few months of collection.

\subsection{Analytical methods}

Hydrostation S samples were analysed for DIC at SIO using manometric methods (Keeling, 1993) and potentiometric titration methods were used for determination of TA (Keeling, 1993). Analytical precision for both DIC and TA at SIO was typically $<0.2 \%$. At BIOS, DIC was determined using coulometric methods with a SOMMA system (Johnson et al., 1993; Bates et al., 1996a; Dickson et al., 2007). During the first two years of sampling, DIC samples were analysed at WHOI (e.g., BATS cruise 1 to 21 ), and subsequently at BIOS. DIC measurements were calibrated with known volumes of pure $\mathrm{CO}_{2}$ gas while certified reference materials (CRM's; Dickson et al., 2007) were routinely analysed each day of analysis. Potentiometric titration methods were also used for determination of TA at BIOS (Bates et al., 1996b). At the beginning of the 1990s, a manual alkalinity titrator was used for determination of TA. This was replaced by an 


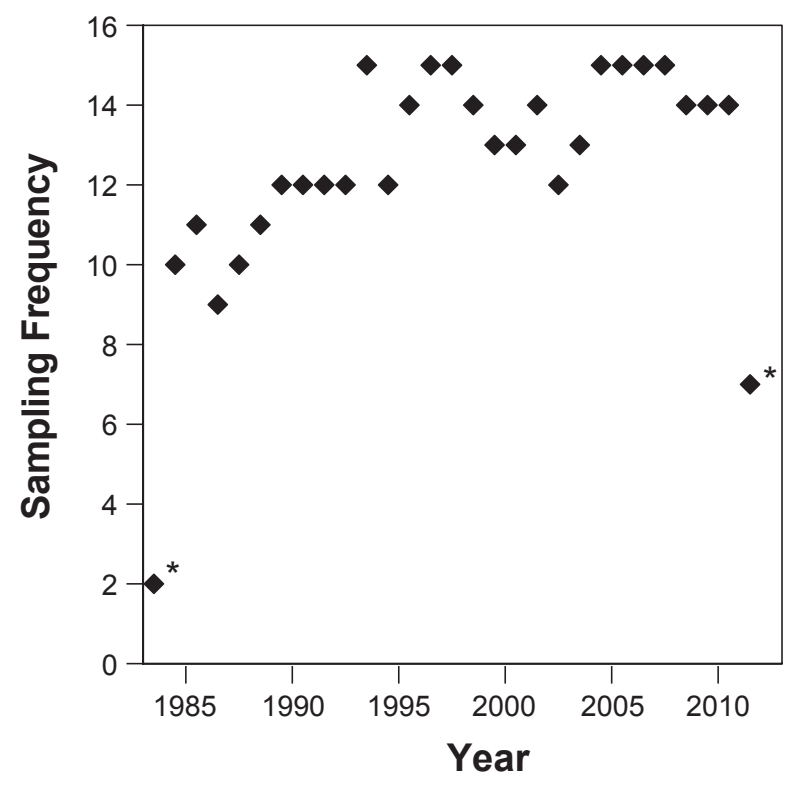

Fig. 1. Sampling frequency or number of cruises each year when seawater carbonate chemistry and other parameters were collected. From September 1988, only BATS cruises are shown with Hydrostation $\mathrm{S}$ cruise beforehand. The * symbol denotes years when the full year was not sampled.

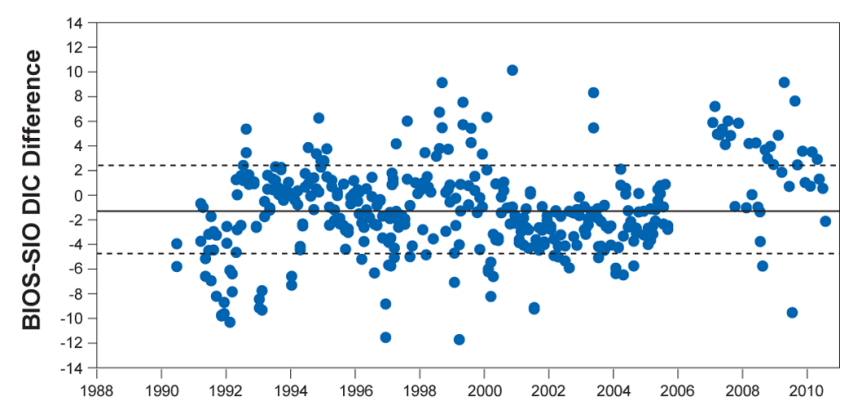

Fig. 2. Comparison of DIC analysed at BIOS and SIO. Differences shown in $\mu \mathrm{mol} \mathrm{kg}-1$.

automated VINDTA 2S (Versatile Instrument for the Determination of Titration Alkalinity) in the early 2000s. For both manual and automated TA systems, 15-20 titration points past the carbonic acid end point were determined for each sample, with TA computed from these titration data using nonlinear least squares methods (Dickson et al., 2007). Surface samples of Sargasso Sea water were also analysed each day prior to sample analyses and CRMs were used routinely to calibrate the TA measurements. Analytical precision for both DIC and TA at BIOS was typically $<0.2 \%$ for several thousand within bottle and between bottle replicate analyses of more than 2000 samples.

\subsection{Comparison of replicate samples analysed at BIOS and SIO}

From 1989-2010, selected replicate surface DIC and TA samples at BATS were analysed independently at BIOS and Scripps using different analytical techniques. Replicate surface and $10 \mathrm{~m}$ depth samples were collected on BATS cruises over a period of twenty years from 1990 to 2010. Comparison of DIC samples analysed independently at BIOS and SIO indicate that the mean difference was $1.24 \pm 3.35 \mu \mathrm{mol} \mathrm{kg}-1$ (Fig. 2; SIO DIC values higher than BIOS values) with a sample number of 373. Comparison of TA samples analysed independently at BIOS and SIO indicate that the mean difference was $0.33 \pm 5.02 \mu \mathrm{mol} \mathrm{kg}{ }^{-1}$ (SIO TA values slightly higher than BIOS values) with a sample number of 290 . Thus, over a period of twenty years, there is no evidence of any systematic analytical biases that would influence the accuracy of data and trends.

\subsection{Compilation of a combined BATS/Hydrostation $S$ record}

Surface Hydrostation S data from September 1983 to September 1988 and BATS data from October 1988 to present (with exceptions) were combined to produce a continuous time-series. For BATS cruises 22-27, surface DIC data from SIO (Keeling, 1993) was used as water-column samples were not collected for the period July-December 1990. For BATS cruises 21-27 and 30-36, TA samples analysed at SIO were used (Keeling, 1993). For Hydrostation S cruise 605698101, and BATS cruises 1-3, 4-20, 79A, 90A, 91A, 100A, 101A, 102A, 113A, 114A, 138, 185A and 186A, TA was calculated from salinity (with an error of $\sim 2.8 \mu \mathrm{mol} \mathrm{kg}{ }^{-1}$; Bates et al., 1996a). Exclusion of these samples from trend analysis did not change results significantly. The locations of Hydrostation S and BATS are separated in space by $\sim 50 \mathrm{~km}$, but analysis of both Hydrostation $\mathrm{S}$ and BATS data at SIO suggests that there is no statistical difference between the two locations. Surface data are shown here but no statistical difference was found if mean DIC and TA were determined for different depth intervals in the mixed layer (using a $0.5^{\circ} \mathrm{C}$ temperature criterion to define mixed layer depth).

\subsection{Computation of seawater carbonate chemistry}

Seawater $p \mathrm{CO}_{2}, \mathrm{pH},\left[\mathrm{CO}_{3}^{2-}\right]$, mineral saturation states for calcite $\left(\Omega_{\text {calcite }}\right)$ and aragonite $\left(\Omega_{\text {aragonite }}\right)$, and the Revelle factor $(\beta)$ were computed from DIC, TA, temperature and salinity data using the programme $\mathrm{CO} 2 \mathrm{calc}$ (Robbins et al., 2010). Carbonic acid dissociation constants (i.e., $\mathrm{pK}_{1}$ and $\mathrm{pK}_{2}$ ) of Mehrbach et al. (1973), as refit by Dickson and Millero (1987) were used for the computation, as well as dissociation constants for $\mathrm{HSO}_{4}^{-}$(Dickson, 1990). GEOSECS and Transient Tracers in the Ocean (TTO) DIC, 

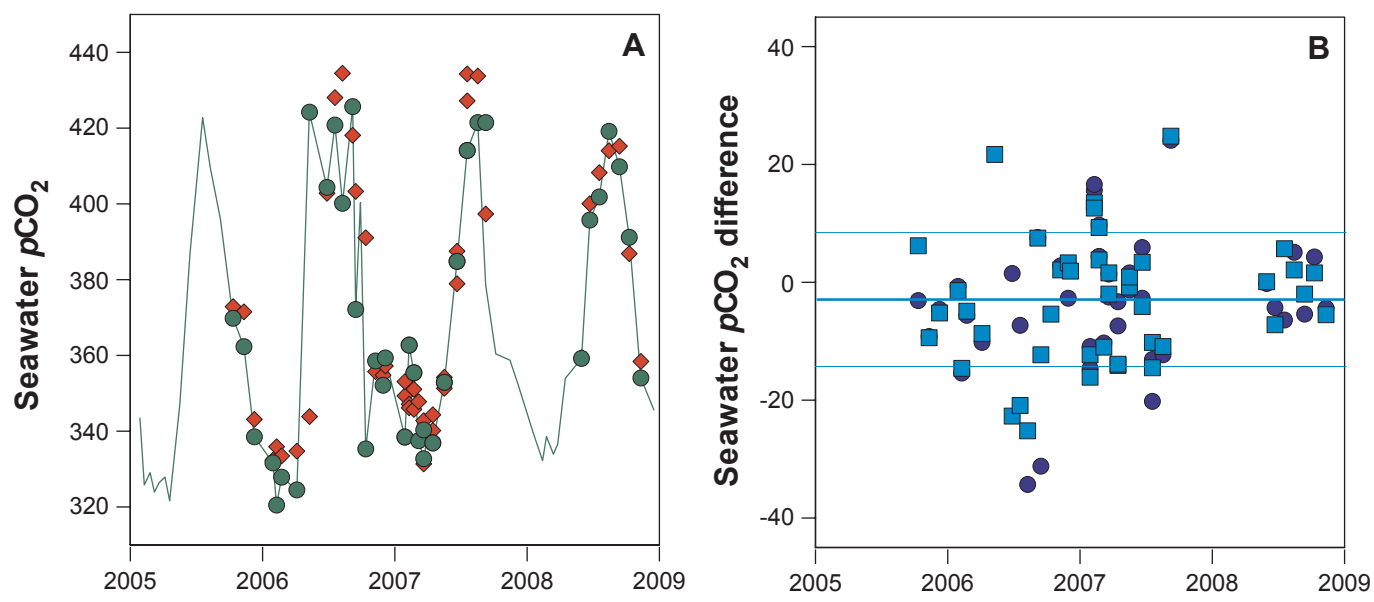

Fig. 3. Comparison of computed seawater $p \mathrm{CO}_{2}$ ( $\mu$ atm) with $p \mathrm{CO}_{2}$ directly measured from the $R / V$ Atlantic Explorer or Bermuda Testbed Mooring (BTM). (A) time-series of computed seawater $p \mathrm{CO}_{2}$ at BATS (black line) with directly measured $p \mathrm{CO}_{2}$ from the $R / V$ Atlantic Explorer and BTM (red symbols). The green symbols denote directly measured $p \mathrm{CO}_{2}$ corrected to the temperature of sampling at BATS. (B). difference between computed seawater $p \mathrm{CO}_{2}$ and directly measured $p \mathrm{CO}_{2}$ from the $R / V$ Atlantic Explorer and BTM (blue symbols; $\mu$ atm). The cyan symbols denote directly measured $p \mathrm{CO}_{2}$ corrected to the temperature of sampling at BATS. Mean and 1 standard deviation are shown in the figure.

TA, temperature and salinity data were taken from the CDIAC site (http://cdiac.ornl.gov). We used the same dissociation constants to compute surface $p \mathrm{CO}_{2}, \mathrm{pH}$ and $\Omega_{\text {aragonite }}$ from GEOSECS and Transient Tracers in the Ocean (TTO) DIC, TA, temperature and salinity data. GEOECS and TTO data available through WAVES (Web-Accessible Visualisation and Extraction System) that allows access to discrete data that are part of the Global Ocean Data Analysis Project (GLODAP) and Carbon in the North Atlantic (CARINA) databases. The strong caveat with regard to using GEOSECS and TTO data is that these data have been adjusted (Tanhua and Wallace, 2005) to account for potential biases associated with the potentiometric determination of DIC at the time of sampling. Thus, caution is urged when using these data for comparison to time-series data at BATS/Hydrostation.

\subsection{Computation of seawater carbonate chemistry}

The computation of seawater $p \mathrm{CO}_{2}$ was compared to direct measurements of $p \mathrm{CO}_{2}$ from the $R / V$ Atlantic Explorer and Bermuda Testbed Mooring (BTM) from 2005 to 2010 (Fig. 3). During this period, 42 direct comparisons were made. Observed seawater $p \mathrm{CO}_{2}$ was collected from BIOS ship $R / V$ Atlantic Explorer (AE) at the BATS site $\left(31^{\circ} 43^{\prime} \mathrm{N}\right.$, $64^{\circ} 10^{\prime} \mathrm{W}$ ) using a $p \mathrm{CO}_{2}$ system calibrated with $4 \mathrm{CO}_{2}$ in-air standards similar to previous methods used at BIOS (Bates et al., 1998). Seawater $p \mathrm{CO}_{2}$ measurements were also made using a $p \mathrm{CO}_{2}$ sensor attached to the Bermuda Testbed Mooring (BTM; $31^{\circ} 41.77^{\prime} \mathrm{N}, 64^{\circ} 10.52^{\prime} \mathrm{W}$; Dickey et al., 2009, http://cdiac.ornl.gov). This system was calibrated with one $\mathrm{CO}_{2}$-in-air standard and deployed from 2005 to 2007.
Both seawater $p \mathrm{CO}_{2}$ systems were calibrated with $\mathrm{CO}_{2}$-inair standards calibrated at CMDL (NOAA).

At the time of sampling for DIC and TA at the BATS site (i.e., time that Niskin sampler was tripped and filled), mean observed $R / V$ Atlantic Explorer and BTM seawater $p \mathrm{CO}_{2}$ were averaged over $1 \mathrm{~h}$ with the mid-point exactly contemporaneous with the time of sampling. Compared to the observed $R / V$ Atlantic Explorer and BTM seawater $p \mathrm{CO}_{2}$ data, computed $p \mathrm{CO}_{2}$ from DIC and TA was lower by a mean of $-4.7 \pm 13.6 \mu \mathrm{atm}$. However, there were slight differences in sampling temperatures and, thus, $R / V$ Atlantic Explorer and BTM seawater $p \mathrm{CO}_{2}$ data were corrected to the SST's at time of DIC/TA sampling at BATS. The mean difference between temperature corrected seawater $p \mathrm{CO}_{2}$ computed at BATS and directly observed from the $R / V$ Atlantic Explorer and BTM was small $(-3.1 \pm 10.8 \mu \mathrm{atm})$. No systematic bias in the computation of seawater $p \mathrm{CO}_{2}$ was apparent.

\subsection{Trend analysis and statistics}

Trend analyses were conducted of the time-series of surface temperature and salinity, seawater carbonate chemistry (DIC, TA, $p \mathrm{CO}_{2}$, Revelle factor, $\beta$ ) and ocean acidification indicators ( $\mathrm{pH},\left[\mathrm{CO}_{3}^{2-}\right], \Omega_{\text {calcite }}$ and $\left.\Omega_{\text {aragonite }}\right)$. Here, trend analysis of salinity normalised DIC (nDIC) and TA (nTA) data were also made in order to account for local evaporation and precipitation changes. These data were normalised to a salinity of 36.6 , as this represents the mean salinity observed at the BATS site (Bates, 2007). Trend analysis was performed with observed data (Table 1) and seasonally detrended data (Table 2). Regression statistics given were slope, error, $r^{2}, p$-value and $n$. Trends with $p$-values greater than 

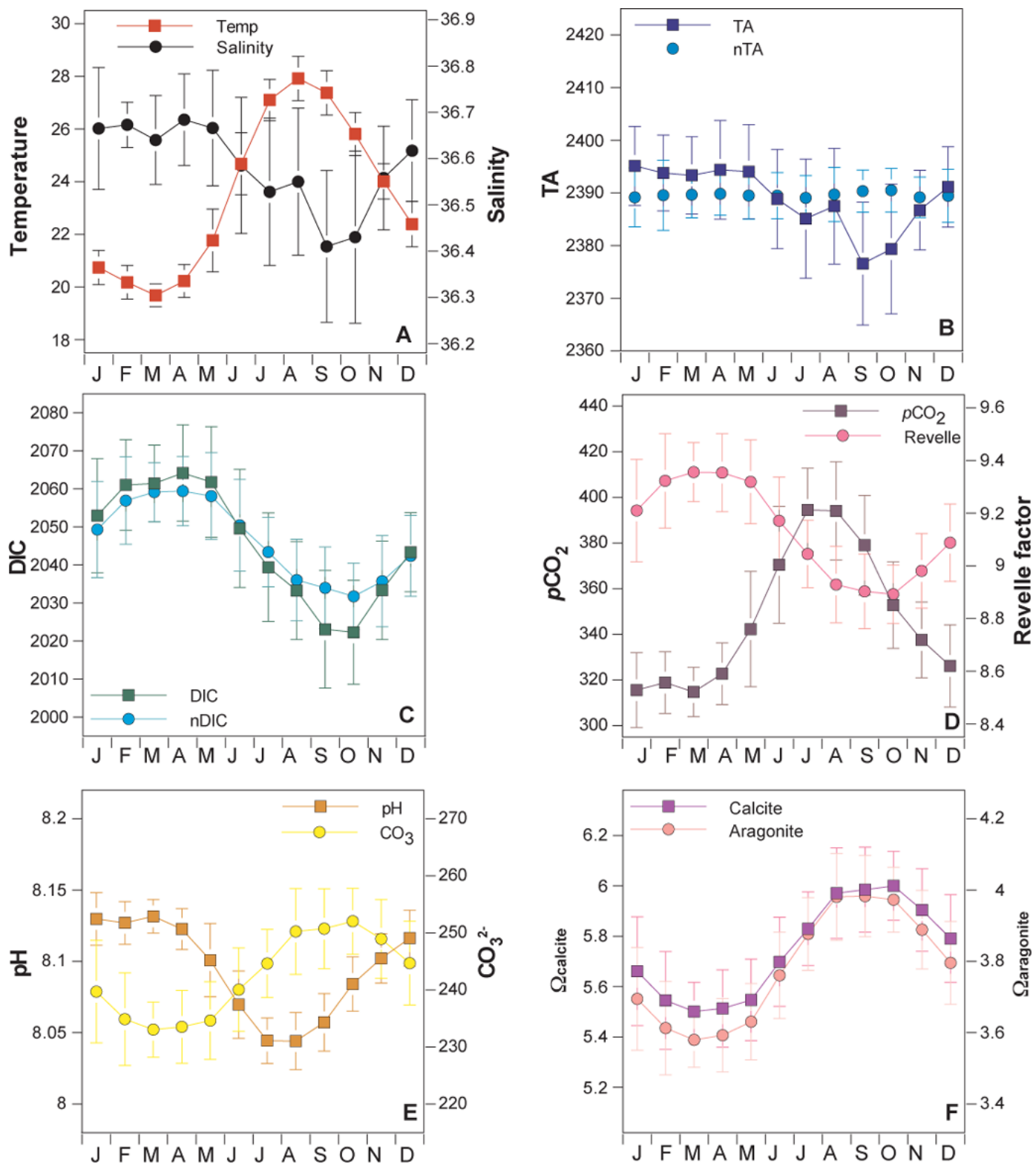

Fig. 4. Mean monthly values for surface temperature and salinity (A), total alkalinity $\left(\mathbf{B}, \mu \mathrm{mol} \mathrm{kg}^{-1}\right)$; $\mathrm{DIC}\left(\mathbf{C}, \mu \mathrm{mol} \mathrm{kg}{ }^{-1}\right)$, seawater $p \mathrm{CO}_{2}$ and Revelle factor $\beta(\mathbf{D}, \mu \mathrm{atm}), \mathrm{pH}$ and $\left[\mathrm{CO}_{3}^{2-}\right]\left(\mathbf{E}, \mu \mathrm{mol} \mathrm{kg}{ }^{-1}\right.$ for $\left.\left[\mathrm{CO}_{3}^{2-}\right]\right)$, and $\Omega_{\text {calcite }}$ and $\Omega_{\text {aragonite }}(\mathbf{F})$, at BATS/Hydrostation S for the period 1983-2011. The standard deviation is shown by y error bars.

0.01 were deemed statistically not significant at the $99 \%$ confidence level.

\subsection{Seasonal detrending of data}

Trends analyses with observed data exhibits seasonal aliasing due to sampling weighting to spring conditions. For example, sea surface temperature (SST) apparently cooled during the 1983-2011 period at a rate of $-0.075 \mathrm{decade}^{-1}$, but this largely reflects a sampling bias that is weighted to springtime conditions. To account for seasonal weighting, the data were also seasonally detrended. Seasonal detrending of the
BATS/hydrostation $\mathrm{S}$ data was accomplished by binning data into appropriate month, with mean values calculated from two or more cruises conducted within a representative month each year. This provides a uniform timestep of approximately 1 month (i.e., 365 or 366 days/12) throughout the timeseries, thereby removing any potential seasonal weighting especially to springtime conditions. The mean seasonality of all parameters are shown in Fig. 4. Second, a mean and standard deviation is then determined each month for the 1983-2011 (Fig. 4), and anomalies computed from monthly data minus mean values. Trends and regression statistics for seasonally 


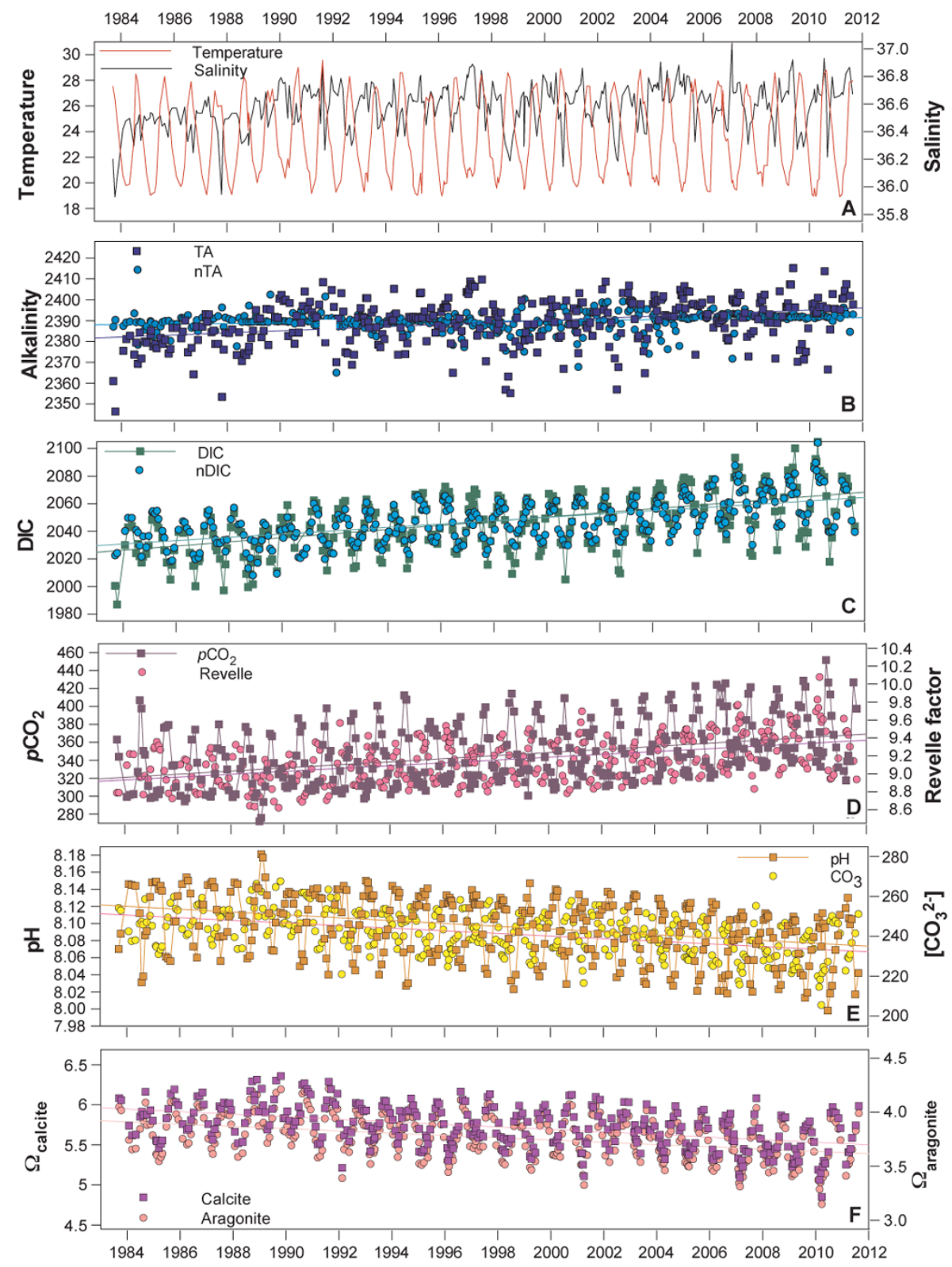

Fig. 5. Long-term observations and trends of surface hydrography, seawater carbonate chemistry and ocean acidification indicators from 1983 to 2011 at the BATS (Bermuda Atlantic Time-series Study; $31^{\circ} 40^{\prime} \mathrm{N}, 64^{\circ} 10^{\prime} \mathrm{W}$ ) and Hydrostation S $\left(32^{\circ} 10^{\prime} \mathrm{N}, 64^{\circ} 30^{\prime} \mathrm{W}\right)$ sites located near Bermuda in the NW Atlantic Ocean. Slopes and statistics of regressions are listed in Table 1. (A) Sea surface temperature $\left({ }^{\circ} \mathrm{C}\right.$; black line) and salinity (red line). (B) Surface total alkalinity (TA, $\mu \mathrm{mol} \mathrm{kg}{ }^{-1}$, blue symbol) and salinity normalised TA (nTA; $\mu \mathrm{mol} \mathrm{kg}{ }^{-1}$, cyan symbol). (C) Surface dissolved inorganic carbon (DIC, $\mu \mathrm{mol} \mathrm{kg}-1$, green symbol) and salinity normalised DIC (nDIC; $\mu \mathrm{mol} \mathrm{kg}{ }^{-1}$, cyan symbol). (D) Seawater $p \mathrm{CO}_{2}$ ( $\mu$ atm; purple symbol) and Revelle factor $(\beta)$ (salmon symbol). (E) Surface seawater $\mathrm{pH}$ (orange symbol) and [CO $\left.{ }_{3}^{2-}\right]$ $\left(\mu \mathrm{mol} \mathrm{kg}{ }^{-1}\right.$, yellow symbol) (F) Surface saturation state of calcite $\left(\Omega_{\text {calcite }}\right)$ (purple symbol) and aragonite $\left(\Omega_{\text {calcite }}\right)$ (light pink symbol).

detrended data are given in Table 2. Removing any potentially seasonal weighting allowed trend analysis of data that had any non-temporal uniformity reduced as much as possible. The caveat to this approach and other approaches (e.g., using a 12 month harmonic fit to the data) is that energy may be lost or gained is that variance may be lost.

\section{Results}

\subsection{Seawater carbonate chemistry changes in surface waters}

The time-series of surface temperature and salinity, seawater carbonate chemistry (DIC, TA, $p \mathrm{CO}_{2}$, Revelle factor, 

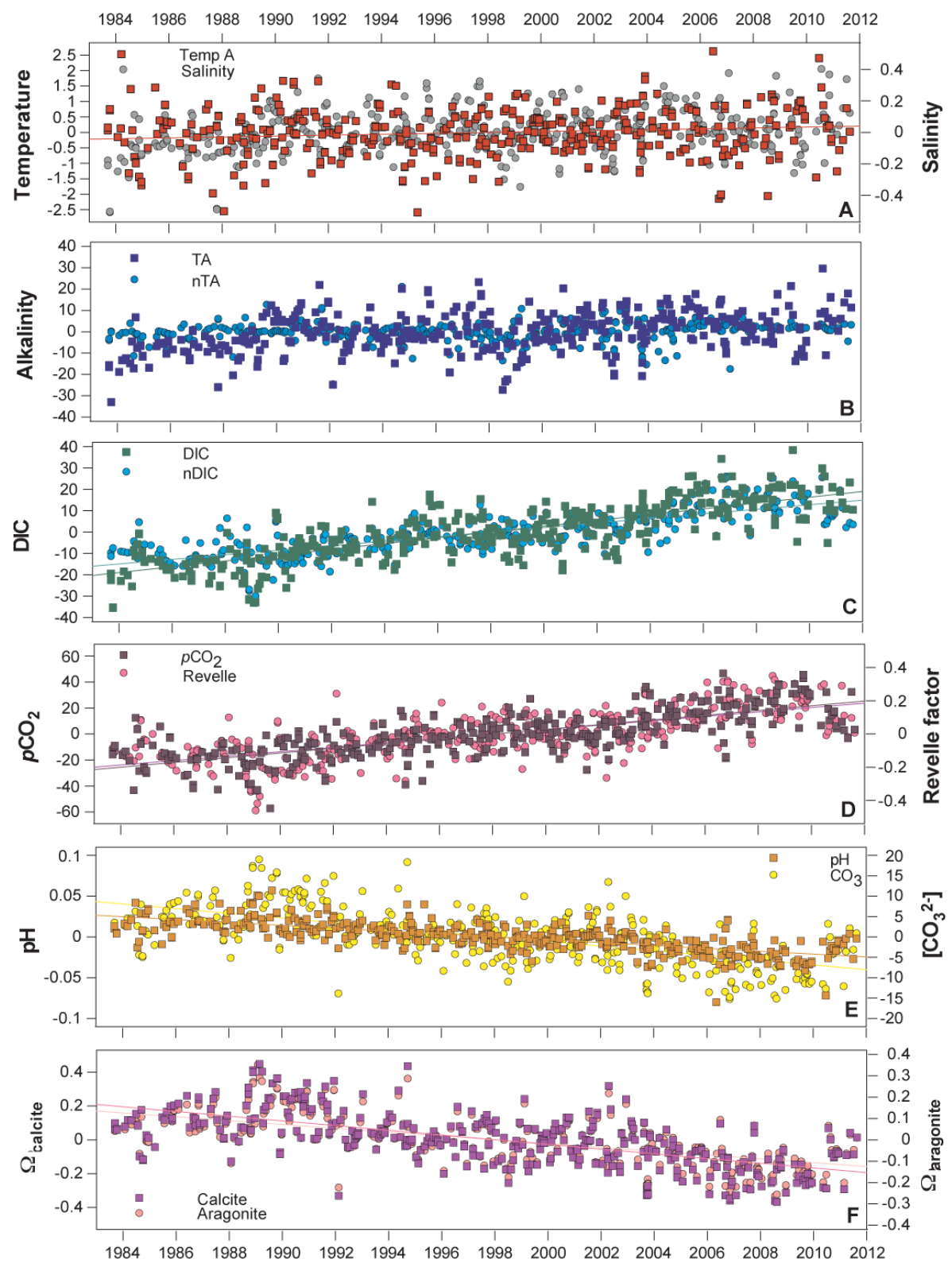

Fig. 6. Long-term anomalies and trends of surface hydrography, seawater carbonate chemistry and ocean acidification indicators from 1983 to 2011 at the BATS (Bermuda Atlantic Time-series Study; $\left.31^{\circ} 40^{\prime} \mathrm{N}, 64^{\circ} 10^{\prime} \mathrm{W}\right)$ and Hydrostation S $\left(32^{\circ} 10^{\prime} \mathrm{N}, 64^{\circ} 30^{\prime} \mathrm{W}\right)$ sites located near Bermuda in the NW Atlantic Ocean. Slopes and statistics of regressions are listed in Table 1. (A) Sea surface temperature $\left({ }^{\circ} \mathrm{C}\right.$; black line) and salinity (red line). (B) Surface total alkalinity (TA, $\mu \mathrm{mol} \mathrm{kg}{ }^{-1}$, blue symbol) and salinity normalised TA (nTA; $\mu \mathrm{mol} \mathrm{kg}{ }^{-1}$, cyan symbol). (C) Surface dissolved inorganic carbon (DIC, $\mu \mathrm{mol} \mathrm{kg}{ }^{-1}$, green symbol) and salinity normalised DIC (nDIC; $\mu \mathrm{mol} \mathrm{kg}{ }^{-1}$, cyan symbol). (D) Seawater $p \mathrm{CO}_{2}$ ( $\mu \mathrm{atm}$; purple symbol) and Revelle factor $(\beta)$ (salmon symbol). (e) Surface seawater $\mathrm{pH}$ (orange symbol) and [CO $\left.{ }_{3}^{2-}\right]$ ( $\mu \mathrm{mol} \mathrm{kg}{ }^{-1}$, yellow symbol) (f) Surface saturation state of calcite $\left(\Omega_{\text {calcite }}\right)$ (purple symbol) and aragonite $\left(\Omega_{\text {calcite }}\right)$ (light pink symbol).

$\beta)$ and ocean acidification indicators $\left(\mathrm{pH},\left[\mathrm{CO}_{3}^{2-}\right], \Omega_{\text {calcite }}\right.$ and $\Omega_{\text {aragonite }}$ ) off Bermuda in the North Atlantic Ocean are shown in Fig. 5. However, these data are subject to seasonal weighting due to additional sampling in springtime and, thus, seasonal detrended data are shown in Fig. 6. Trends and regression statistics for seasonally detrended data are given in Table 2.

\subsection{Warming and salinity increases in surface waters}

There is evidence for warming and increased salinity of surface waters of the North Atlantic subtropical gyre near Bermuda. Time series analysis of data at BATS reveal significant long-term trends in the temperature and salinity of the surface ocean increasing at 


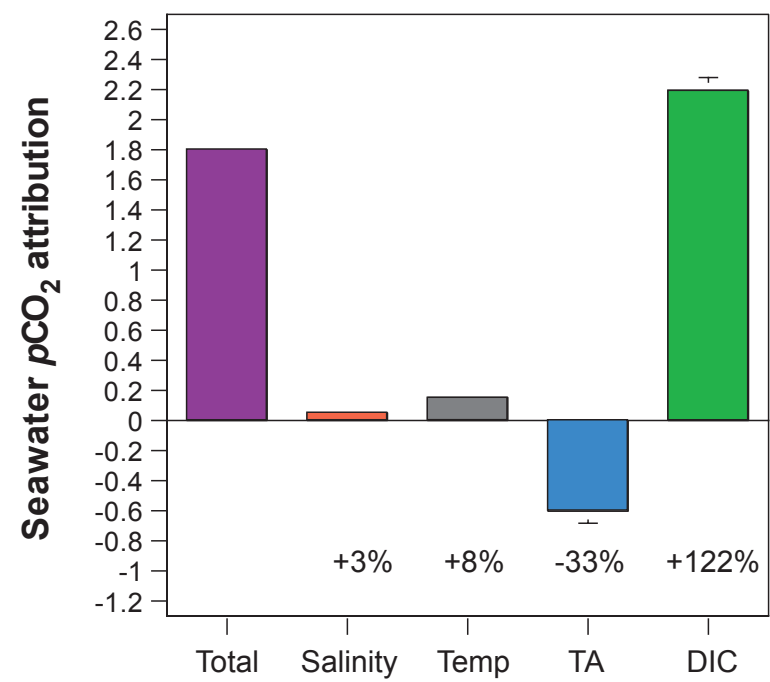

Fig. 7. Long-term trend in seawater $p \mathrm{CO}_{2}$ (purple) and its attribution to long-term changes in salinity, temperature, TA and DIC (green). The relative attribution of change was computed using CO2calc (Robbins et al., 2010) using mean temperature, salinity, TA and DIC values observed at BATS. Mean values and trends taken from Table 2 .

rates of $\sim 0.011 \pm 0.006^{\circ} \mathrm{C} \mathrm{yr}^{-1}\left(\sim 0.11^{\circ} \mathrm{C}\right.$ decade $\left.^{-1}\right)$ and $0.0054 \pm 0.0001 \mathrm{yr}^{-1}$, respectively (Table 2; Fig. 6). However, it should be noted that the surface temperature trend is not statistically significant at the $95 \%$ level ( $p$-value $>0.05$ ), but similar temperature trends that are statistically significant have been observed within the upper $400 \mathrm{~m}$ at BATS and Hydrostation $\mathrm{S}$ over the last 55 years with temperature and salinity increasing at rates of $\sim 0.01^{\circ} \mathrm{C} \mathrm{yr}^{-1}$ and $0.002 \mathrm{yr}^{-1}$, respectively (Joyce et al., 1999). Similar long-term changes in surface temperatures have been observed across the subtropical gyre of the North Atlantic Ocean (Grist et al., 2010) indicating a system level change in the marine environment. The observed increase in surface salinity near Bermuda is also evident across the North Atlantic Ocean subtropical gyre (Zhang et al., 2011), appears related to coordinated changes in freshwater fluxes and modes of climate variability such as the North Atlantic Oscillation (Hurrell and Deser, 2010).

\subsection{Trends in seawater carbonate chemistry of surface waters}

Our observations near Bermuda also show multi-decadal changes in seawater carbonate chemistry in response to anthropogenic $\mathrm{CO}_{2}$ uptake by surface waters. Direct observations of DIC, computed seawater $p \mathrm{CO}_{2}$ and Revelle factor $(\beta)$ exhibit significant increases over the last three decades (Fig. 6; Table 2). Surface DIC and salinity normalised DIC (i.e., nDIC) have increased by $1.39 \pm 0.06$ and $1.08 \pm 0.06 \mu \mathrm{mol} \mathrm{kg}^{-1} \mathrm{yr}^{-1}$, respectively, a change of nearly $40 \mu \mathrm{mol} \mathrm{kg}^{-1}$, or $\sim 2 \%$ from 1983 to 2011. Sim- ilar changes were observed previously at BATS (Bates, 2007) and attributed to the uptake of anthropogenic $\mathrm{CO}_{2}$ from the atmosphere (Gruber et al., 2002; Bates et al., 2002). Similar changes in DIC over shorter timescales have been observed elsewhere off Hawaii (Dore et al., 2003; 2009) and the Canary Islands (Santana-Casiano et al., 2007; Gonzalez-Davila et al., 2010). TA increased slightly by $0.48 \pm 0.07 \mu \mathrm{mol} \mathrm{kg}^{-1} \mathrm{yr}^{-1}$, attributed here to gradual increase in the salinity of surface subtropical gyre waters. Salinity normalised TA (nTA) increased slightly at a rate of $0.10 \pm 0.03 \mu \mathrm{mol} \mathrm{kg}{ }^{-1} \mathrm{yr}^{-1}$, but since this trend was not statistically significant, there was no definitive evidence that nTA has changed during the last three decades (Table 2).

\section{Discussion}

\subsection{Changes in seawater $p \mathrm{CO}_{2}$ with time and its attribution}

Surface seawater $\quad p \mathrm{CO}_{2}$ exhibited significant increases over the last 3 decades, increasing at a rate of

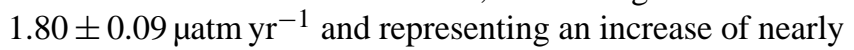
$55 \mu$ atm or $20 \%$ from 1983 to 2011 (Fig. 6; Table 2). The increasing trend in seawater $p \mathrm{CO}_{2}$ can be attributed to changes in DIC, TA, temperature and salinity (Fig. 7). The trend in observed DIC would increase seawater $p \mathrm{CO}_{2}$ by $+122 \%$, but this effect is counteracted by a small increase in TA that decreases $p \mathrm{CO}_{2}(-33 \%)$. Trends in temperature $(+8 \%)$ and salinity $(+3 \%)$ have minor impacts on calculated seawater $p \mathrm{CO}_{2}$. Similar trends and attribution of trends have been shown for observed $p \mathrm{CO}_{2}$ across the North Atlantic in the seasonally stratified subtropical gyre (Bates, 2011) where the increase in seawater $p \mathrm{CO}_{2}$ can be attributed to non-temperature effects (i.e., sum of DIC, TA and salinity changes). Over shorter timescales, similar trends in surface seawater $p \mathrm{CO}_{2}$ have been observed elsewhere off Hawaii (Dore et al., 2003; 2009) and the Canary Islands (Santana-Casiano et al. 2007; Gonzalez-Davila et al., 2010).

\subsection{Changes in the ocean $\mathrm{CO}_{2}$ sink?}

These observations infer that the ocean $\mathrm{CO}_{2}$ sink in the subtropical gyre has not changed significantly over the last three decades. Similar to previous observations at BATS, seawater $p \mathrm{CO}_{2}$ has increased at a comparable rate to atmospheric $p \mathrm{CO}_{2}$ (Bates, 2007; Takahashi et al., 2009; Table $2,1.72 \pm 0.01 \mu \mathrm{atm} \mathrm{yr}^{-1}$ ) from 1983 to present. These trends indicate that the driving force for air-sea $\mathrm{CO}_{2}$ gas exchange (i.e., $\Delta p \mathrm{CO}_{2} ; p \mathrm{CO}_{2}$ difference between atmosphere and seawater) has not changed significantly over the last 3 decades. One might, therefore, think that the ocean $\mathrm{CO}_{2}$ sink near Bermuda has not changed significantly over time. However, it should be noted that windspeed also contributes in addition to $\Delta p \mathrm{CO}_{2}$ to the magnitude of air-sea $\mathrm{CO}_{2}$ gas exchange. There is some evidence that the annual $\mathrm{CO}_{2}$ sink 
Table 1. Long-term trends (1983-2011) of surface hydrography and seawater carbonate chemistry with regression statistics (slope and error, $n, r^{2}$ and $p$-value). This includes surface seawater temperature, salinity, DIC, nDIC, TA, nTA, atmospheric $p \mathrm{CO}_{2}\left(p \mathrm{CO}_{2}^{\mathrm{atm}}\right)$, and

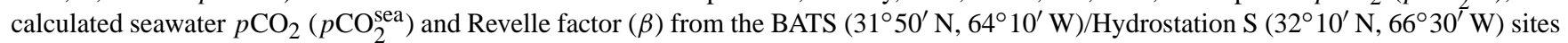
in the North Atlantic Ocean. Please see text for details on the $\mathrm{CO}_{2}$-carbonic acid system computation and salinity normalisation procedures. Observations of atmospheric $p \mathrm{CO}_{2}$ data come from two atmospheric monitoring sites (Terceira Island, Açores, September 1983-September 1988; Bermuda, August 1988-December 2010).

\begin{tabular}{|c|c|c|c|c|c|}
\hline Parameter & Period & Slope and std error & $n$ & $r^{2}$ & $p$-value \\
\hline \multicolumn{6}{|l|}{ Hydrography } \\
\hline Temperature & 09/1983-07/2011 & $-0.0075 \pm 0.021^{\circ} \mathrm{C} \mathrm{yr}^{-1}$ & 362 & 0.00 & 0.72 \\
\hline Salinity & 09/1983-07/2011 & $+0.0058 \pm 0.0010 \mathrm{yr}^{-1}$ & 362 & 0.08 & $<0.01$ \\
\hline \multicolumn{6}{|c|}{ Ocean acidification indicators } \\
\hline $\mathrm{pH}$ & 09/1983-07/2011 & $-0.0016 \pm 00022 \mathrm{yr}^{-1}$ & 358 & 0.13 & $<0.01$ \\
\hline $\mathrm{CO}_{3}^{2-}$ & $09 / 1983-07 / 2011$ & $-0.64 \pm 0.06 \mu \mathrm{mol} \mathrm{kg}^{-1} \mathrm{yr}^{-1}$ & 358 & 0.24 & $<0.01$ \\
\hline$\Omega_{\text {calcite }}$ & 09/1983-07/2011 & $-0.0152 \pm 0.0016 \mathrm{yr}^{-1}$ & 358 & 0.21 & $<0.01$ \\
\hline$\Omega_{\text {aragonite }}$ & 09/1983-07/2011 & $-0.0100 \pm 0.0012 \mathrm{yr}^{-1}$ & 358 & 0.16 & $<0.01$ \\
\hline \multicolumn{6}{|c|}{ Seawater carbonate chemistry } \\
\hline DIC & 09/1983-07/2011 & $+1.53 \pm 0.12 \mu \mathrm{mol} \mathrm{kg}^{-1} \mathrm{yr}^{-1}$ & 361 & 0.32 & $<0.01$ \\
\hline $\mathrm{nDIC}$ & 09/1983-07/2011 & $+1.20 \pm 0.09 \mu \mathrm{mol} \mathrm{kg}^{-1} \mathrm{yr}^{-1}$ & 361 & 0.35 & $<0.01$ \\
\hline $\mathrm{TA}$ & 09/1983-07/2011 & $+0.50 \pm 0.07 \mu \mathrm{mol} \mathrm{kg}^{-1} \mathrm{yr}^{-1}$ & 361 & 0.12 & $<0.01$ \\
\hline nTA & 09/1983-07/2011 & $+0.12 \pm 0.03 \mu \mathrm{mol} \mathrm{kg}^{-1} \mathrm{yr}^{-1}$ & 361 & 0.04 & $<0.01$ \\
\hline$p \mathrm{CO}_{2}^{\text {sea }}$ & 09/1983-07/2011 & $+1.62 \pm 0.21 \mu \mathrm{atm} \mathrm{yr}{ }^{-1}$ & 358 & 0.16 & $<0.01$ \\
\hline$p \mathrm{CO}_{2}^{\mathrm{atm}}$ & $09 / 1983-12 / 2010$ & $+1.72 \pm 0.01 \mu \mathrm{atm} \mathrm{yr}^{-1}$ & 1825 & 0.89 & $<0.01$ \\
\hline Revelle factor $(\beta)$ & 09/1983-07/2011 & $+0.015 \pm 0.0014 \mathrm{yr}^{-1}$ & 358 & 0.24 & $<0.01$ \\
\hline
\end{tabular}

has increased slightly due to higher annual windspeeds in the 2000s observed near Bermuda (Bates, 2007), perhaps in response to shift in the winter North Atlantic Oscillation from positive to neutral/negative over the last 2 decades (Hurrell and Deser, 2010; Bates, 2012). Other studies have also shown that with observations conducted over time periods longer than 2 decades, seawater $p \mathrm{CO}_{2}$ has increased at approximately the same rate as the atmosphere (Bates et al., 2002; McKinley et al., 2011) with longer term observations smoothing out shorter term variability. Such studies suggest that analysis of the $\mathrm{CO}_{2}$ sink or source status using data that has a relatively short duration $(<10$ years) may not be sufficient to determine whether the North Atlantic Ocean $\mathrm{CO}_{2}$ sink has decreased over time (e.g., Schuster and Watson, 2007; Schuster et al., 2009; Watson et al., 2009). Such assessments may require a longer term view especially in light of this and other studies (McKinley et al., 2011); and especially when deciphering anthropogenic secular trends from natural variability imparted by such phenomena as the NAO (Joyce et al., 1999; Gruber et al., 2002; Hurrell and Deser, 2010) and Atlantic Multidecadal Oscillation (McKinley et al., 2011). For example, in the last couple of years (20102011; Figs. 5 and 6) there was a lowering of surface seawater $p \mathrm{CO}_{2}$ which appears associated with a change in the NAO state (Bates, 2012). Thus, undertaking trend analysis over the last decade would show a much reduced increase in seawater $p \mathrm{CO}_{2}$ compared to the atmosphere with the inference that the $\mathrm{CO}_{2}$ sink in this region had increased. This may well be the case over the short-term, but over several decades it appears that $\Delta p \mathrm{CO}_{2}$ values have not changed significantly and, thus, there is little evidence of any substantial change in the $\mathrm{CO}_{2}$ sink in the subtropical gyre of the North Atlantic near Bermuda.

In addition, over the 1983-2011 period, the Revelle factor $(\beta)$ has increased at a rate of $0.0137 \pm 0.0008 \mathrm{yr}^{-1}$ or $\sim 0.41$ over the last 3 decades. This indicates that the buffer capacity of subtropical gyre surface waters to absorb $\mathrm{CO}_{2}$ has gradually reduced over time, confirming previous model studies that predict an increasing trend in $\beta$ at BATS and for the North Atlantic Ocean in response to the ocean uptake of anthropogenic $\mathrm{CO}_{2}$ from the atmosphere (Thomas et al., 2007).

\subsection{The signal of ocean acidification in the North Atlantic Ocean}

The BATS/Hydrostation S time-series data allow direct detection of the signal of ocean acidification in surface waters of the North Atlantic. The uptake of anthropogenic $\mathrm{CO}_{2}$ from the atmosphere by the ocean changes seawater chemistry through chemical equilibrium of $\mathrm{CO}_{2}$ with seawater. Dissolved $\mathrm{CO}_{2}$ forms a weak acid and the $\mathrm{pH}$ and $\left[\mathrm{CO}_{3}^{2-}\right]$ decrease as seawater absorbs $\mathrm{CO}_{2}$, a process termed ocean 
Table 2. Seasonally detrended long-term trends (1983-2011) of surface hydrography and seawater carbonate chemistry with regression statistics (slope and error, $n, r^{2}$ and $p$-value). This table includes trend analysis of surface hydrography including temperature and salinity, seawater carbonate chemistry (i.e., DIC, nDIC, TA, nTA, atmospheric $p \mathrm{CO}_{2}\left(p \mathrm{CO}_{2}^{\text {atm }}\right)$, and calculated seawater $p \mathrm{CO}_{2}\left(p \mathrm{CO}_{2}^{\text {sea }}\right)$ and $\operatorname{Revelle}$ factor $(\beta)$ anomalies) and indicators of seawater carbonate chemistry changes (e.g., $\mathrm{pH},\left[\mathrm{CO}_{3}^{2-}\right]$, and mineral saturation states of calcite $\left(\Omega_{\text {calcite }}\right)$ and aragonite $\left(\Omega_{\text {arag }}\right)$ from the BATS $\left(31^{\circ} 40^{\prime} \mathrm{N}, 64^{\circ} 10^{\prime} \mathrm{W}\right)$ and Hydrostation $\mathrm{S}\left(32^{\circ} 10^{\prime} \mathrm{N}, 64^{\circ} 30^{\prime} \mathrm{W}\right)$ sites in the North Atlantic Ocean. Please see text for details on the seawater carbonate chemistry computation and salinity normalisation procedures. Observations of atmospheric $p \mathrm{CO}_{2}$ data come from two atmospheric monitoring sites (Terceira Island, Açores, September 1983-September 1988; Bermuda, August 1988-December 2010). Please see text for details on the methods for removing seasonal trends.

\begin{tabular}{|c|c|c|c|c|c|c|}
\hline Parameter & Period & $\begin{array}{r}30 \mathrm{yr} \text { change } \\
\text { (and units if applicable) }\end{array}$ & $\begin{array}{l}\text { slope and std error } \\
\text { (and units if applicable) }\end{array}$ & $n$ & $r^{2}$ & $p$-value \\
\hline \multicolumn{7}{|c|}{ Hydrography and seawater carbonate chemistry } \\
\hline Temperature & 09/1983-07/2011 & $+0.33^{\circ} \mathrm{C}$ & $+0.011 \pm 0.006^{\circ} \mathrm{C} \mathrm{yr}^{-1}$ & 320 & 0.01 & 0.06 \\
\hline Salinity & 09/1983-07/2011 & +0.162 & $+0.0054 \pm 0.0001$ & 320 & 0.09 & $<0.01$ \\
\hline DIC & 09/1983-07/2011 & $+41.7 \mu \mathrm{mol} \mathrm{kg}-1$ & $+1.39 \pm 0.06 \mu \mathrm{mol} \mathrm{kg}^{-1} \mathrm{yr}^{-1}$ & 319 & 0.63 & $<0.01$ \\
\hline nDIC & 09/1983-07/2011 & $+32.4 \mu \mathrm{mol} \mathrm{kg}-1$ & $+1.08 \pm 0.05 \mu \mathrm{mol} \mathrm{kg}{ }^{-1} \mathrm{yr}^{-1}$ & 319 & 0.61 & $<0.01$ \\
\hline TA & 09/1983-07/2011 & $+14.6 \mu \mathrm{mol} \mathrm{kg}-1$ & $+0.48 \pm 0.07 \mu \mathrm{mol} \mathrm{kg}^{-1} \mathrm{yr}^{-1}$ & 319 & 0.14 & $<0.01$ \\
\hline nTA & 09/1983-07/2011 & $+3.0 \mu \mathrm{mol} \mathrm{kg}-1$ & $+0.10 \pm 0.03 \mu \mathrm{mol} \mathrm{kg}^{-1} \mathrm{yr}^{-1}$ & 319 & 0.03 & $<0.01$ \\
\hline$p \mathrm{CO}_{2}^{\text {sea }}$ & 09/1983-07/2011 & $+54.4 \mu \mathrm{atm}$ & $+1.80 \pm 0.09 \mu \operatorname{atm~yr}^{-1}$ & 319 & 0.53 & $<0.01$ \\
\hline$p \mathrm{CO}_{2}^{\mathrm{atm}}$ & 09/1983-12/2010 & $+51.6 \mu \mathrm{atm}$ & $+1.72 \pm 0.01 \mu \mathrm{atm} \mathrm{yr}^{-1}$ & 1825 & 0.89 & $<0.01$ \\
\hline Revelle & 09/1983-07/2011 & +0.41 & $+0.0137 \pm 0.0008$ & 319 & 0.50 & $<0.01$ \\
\hline \multicolumn{7}{|c|}{ Ocean acidification indicators } \\
\hline $\mathrm{pH}$ & 09/1983-07/2011 & -0.0501 & $-0.00174 \pm 0.0001$ & 319 & 0.50 & $<0.01$ \\
\hline $\mathrm{CO}_{3}^{2-}$ & 09/1983-07/2011 & $-17.5 \mu \mathrm{mol} \mathrm{kg}{ }^{-1}$ & $-0.58 \pm 0.04 \mu \mathrm{mol} \mathrm{kg}^{-1} \mathrm{yr}^{-1}$ & 319 & 0.41 & $<0.01$ \\
\hline$\Omega_{\text {aragonite }}^{3}$ & 09/1983-07/2011 & -0.246 & $-0.0091 \pm 0.0006$ & 319 & 0.39 & $<0.01$ \\
\hline$\Omega_{\text {calcite }}$ & 09/1983-07/2011 & -0.391 & $-0.0141 \pm 0.0009$ & 319 & 0.42 & $<0.01$ \\
\hline
\end{tabular}

acidification (Caldeira and Wickett, 2003, 2005). The effects of ocean acidification are potentially far-reaching in the global ocean, particularly for organisms that secrete $\mathrm{CaCO}_{3}$ skeletons, tests or shells and for marine ecosystems where calcification and $\mathrm{pH}$ controls on biogeochemical processes are important factors (e.g., Fabry et al., 2009). Relevant indicators of ocean acidification include seawater $\mathrm{pH}$, but also $\left[\mathrm{CO}_{3}^{2-}\right]$ and, thus, saturation states for $\mathrm{CaCO}_{3}$ minerals (i.e., $\Omega_{\text {calcite }}$ and $\left.\Omega_{\text {aragonite }}\right)$. The typical $\mathrm{pH}$ range of surface waters is between 7.8 and 8.4 in the open ocean and the ocean remains mildly alkaline at present. At BATS, the mean $\mathrm{pH}$ is 8.094 with a range of 8.00-8.18 (Fig. 5).

The BATS site near Bermuda constitutes the longest time-series record of ocean acidification anywhere in the global ocean (Fig. 6; Bates, 2007). Trend analysis shows that the primary indicator of ocean acidification, seawater $\mathrm{pH}$, has decreased at a rate of $-0.0017 \pm 0.0001 \mathrm{yr}^{-1}$, a total decline in seawater $\mathrm{pH}$ of $\sim 0.05$ over the past 3 decades (Fig. 6; Table 2). This represents a $\sim 12 \%$ increase in hydrogen ion concentration since 1983. Other indicators of ocean acidification at BATS such as $\left[\mathrm{CO}_{3}^{2-}\right]$, $\Omega_{\text {calcite }}$ and $\Omega_{\text {aragonite }}$ have also decreased at a rate of $-0.58 \pm 0.041 \mu \mathrm{mol} \mathrm{kg} \mathrm{kr}^{-1},-0.0141 \pm 0.0009 \mathrm{yr}^{-1}$, and $-0.0091 \pm 0.0006 \mathrm{yr}^{-1}$, respectively (Table 2). Trend analysis at BATS and other published trends for three other ocean time-series sites indicate that surface seawater $\mathrm{pH}$ has decreased at a rate of -0.0014 to $-0.0019 \mathrm{yr}^{-1}$ (e.g., Bates and Peters, 2007; Bates, 2007; Dore et al., 2009; GonzalezDavila et al., 2010; Byrne et al., 2010).

\section{Conclusions}

The long term ocean observations near Bermuda constitute the longest running time-series of changes in seawater carbonate chemistry due to the uptake of anthropogenic $\mathrm{CO}_{2}$ and resulting ocean acidification impacts. Such records and those from other time-series sites (Dore et al., 2009; Gonzalez-Davila et al., 2010; Olafsson et al., 2010) provide critically needed data showing that such changes are due to anthropogenic $\mathrm{CO}_{2}$ release and absorption by the global ocean and to test ocean-atmosphere models (e.g., Bates, 2007; McKinley et al., 2011) that are used for predictive climate-change purposes. Before regular sampling began at the Hydrostation S in 1983 and later at the BATS site in 1988, there was occasional sampling in the North Atlantic subtropical gyre near Bermuda through the GEOSECS and Transient Tracers in the Ocean (TTO) projects. Here, we compute surface $p \mathrm{CO}_{2}, \mathrm{pH}$ and $\Omega_{\text {aragonite }}$ from surface GEOSECS and TTO DIC and total alkalinity data (Kroopnick et al., 1972; Brewer et al., 1985). Combined with BATS/Hydrostation S 


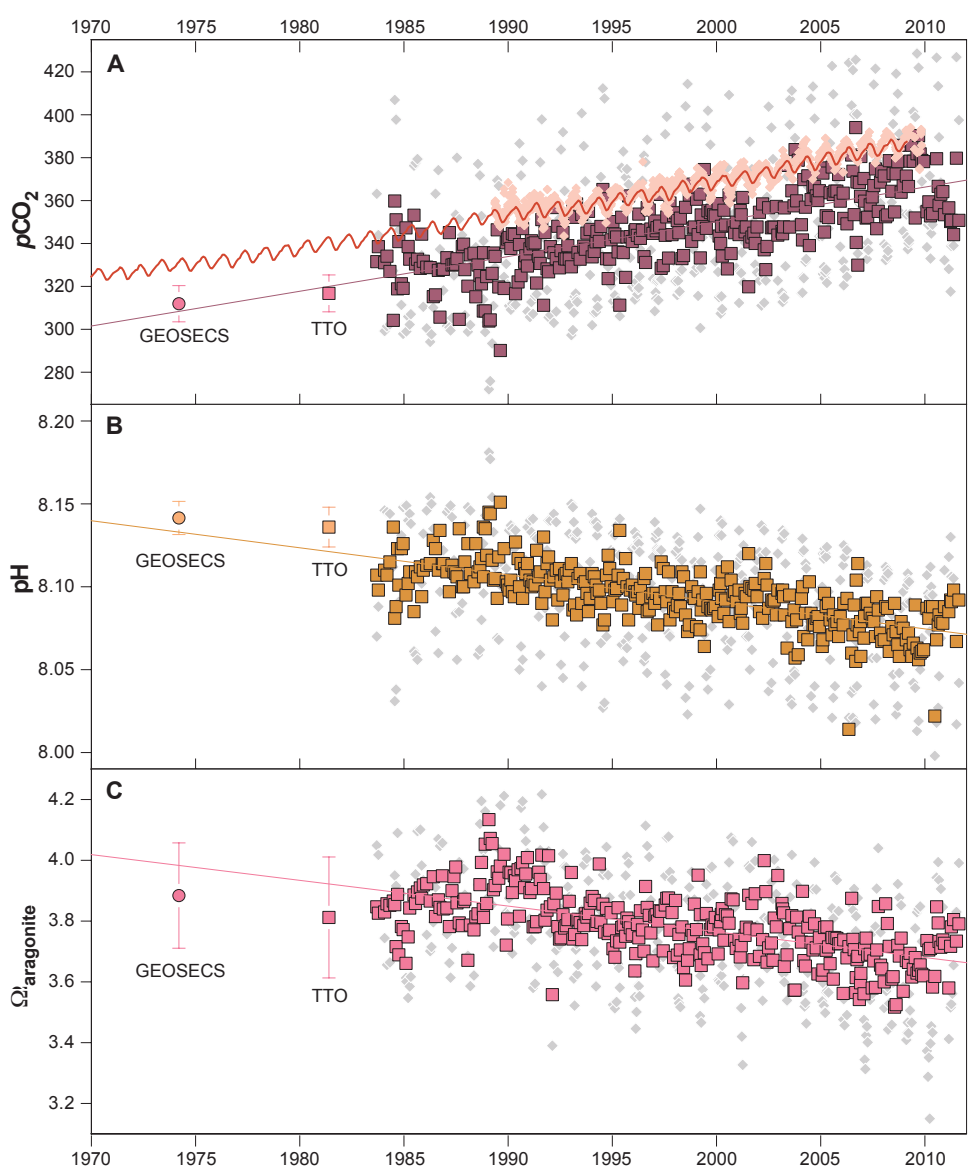

Fig. 8. Time-series of atmospheric and ocean $p \mathrm{CO}_{2}, \mathrm{pH}$ and aragonite saturation states. (A) time-series of atmospheric $p \mathrm{CO}_{2}$ (ppm) from Mauna Loa, Hawaii (red line), and Bermuda (pink symbol), and surface ocean seawater $p \mathrm{CO}_{2}$ ( $\mu$ atm) at the Bermuda Atlantic Time-series Study (BATS) site off Bermuda. Observed (grey) and seasonally detrended (purple) surface ocean seawater $p \mathrm{CO}_{2}$ levels are shown. Earlier seawater data from the GEOSECS (stations $67^{\circ} 58^{\circ} \mathrm{W}, 33^{\circ} 59^{\prime} \mathrm{N} ; 56^{\circ} 33^{\prime} \mathrm{W}, 33^{\circ} 20^{\prime} \mathrm{N}$ ) and TTO (stations $67^{\circ} 21^{\circ} \mathrm{W}, 34^{\circ} 41^{\prime} \mathrm{N} ; 61^{\circ} 20^{\circ} \mathrm{W}$, $34^{\circ} 42^{\prime} \mathrm{N} ; 56^{\circ} 11^{\prime} \mathrm{W}, 32^{\circ} 08^{\prime} \mathrm{N}$ ) expeditions in the North Atlantic Ocean are also shown in this and following panels. (B) time-series of surface ocean seawater $\mathrm{pH}$ at the BATS site off Bermuda. Observed (grey) and seasonally detrended (orange) seawater pH are shown. (C). time-series of surface ocean aragonite saturation state $\left(\Omega_{\text {aragonite }}\right)$ for calcium carbonate at the BATS site off Bermuda. Observed (purple) and seasonally detrended (purple line) seawater $\Omega_{\text {aragonite }}$ are shown.

data, this extends the time-series records of computed surface $p \mathrm{CO}_{2}, \mathrm{pH}$ and $\Omega_{\text {aragonite }}$ back to the early 1970s (Fig. 8). These data were sampled within $200 \mathrm{~km}$ of Bermuda (but not at BATS/Hydrostation) and both surface $p \mathrm{CO}_{2}, \mathrm{pH}$ and $\Omega_{\text {aragonite }}$ data from GEOSECS and TTO fall close to the regression lines for these parameters (from Table 1, Fig. 2). The trend line is hindcast for seawater carbonate chemistry in Fig. 8 into the 1970s, but the actual trend in the 1970s would likely follow the nonlinear trend of the atmospheric $p \mathrm{CO}_{2}$ record. A final caveat in showing the GEOSECS/TTO data is that these data are adjusted (Tanhua and Wallace, 2005) to account for measurement biases and not adjusted for seasonality, so some caution is urged in comparing these data with those from BATS/Hydrostation S. Notwithstanding these issues, the trends established at BATS/Hydrostation S appear to extend back to the early 1970 s, constituting a nearly con- tinuous 40 year record of changing seawater carbonate chemistry and ocean acidification indicators.

Acknowledgements. The authors wish to express their deep appreciation to many following individuals: Anthony H. Knap (principal investigator) and other present and past BATS investigators, Anthony F. Michaels, Dennis A. Hansell, Deborah K. Steinberg, Craig A. Carlson and Michael W. Lomas. We are deeply in debt to the pioneering work of the late Dave Keeling (d. 2005). Past and present analysts for seawater carbonate chemistry at BIOS for the BATS project include Frances A. Howse, Julian Mitchell, Brett Purinton with data QC/QA by Christine Pequignet and Marlene Jeffries, and at the Scripps Institution of Oceanography, Peter Guenther, Timothy Lueker and Guy Emanuele. Many BIOS scientists and technicians have spent dedicated time at sea sampling at BATS and Hydrostation S, including: Timothy J. Jickells, Rachel Dow, Kandace Binkley, Ann Close, Kjell Gundersen, Jens 
Sorensen, Elizabeth Caporelli, Fred Bahr, Steven J. Bell, Patrick Hyder, Vivienne Lochhead, Paul Lethaby, Marta Sanderson, Megan Roadman, Debra A. Lomas, Mary-Margaret Murphy, Sybille Pluvinage, Lilia M. Jackman, Andreas J. Andersson, Matthew A. Tiahlo, Jonathan D. Whitefield, Kevin Lew, Dafydd (Gwyn) Evans, Elise van Meerssche, James Sadler, Sam Monk and Matthew Wilkinson. The captains and crews of the $R / V$ Weatherbird, $R / V$ Weatherbird II, R/V Cape Hatteras and $R / V$ Atlantic Explorer. The National Science Foundation is thanked for its support of both Hydrostation S and BATS projects.

Edited by: G. Herndl

\section{References}

Bates, N. R.: Interannual changes of oceanic $\mathrm{CO}_{2}$ and biogeochemical properties in the Western North Atlantic subtropical gyre, Deep-Sea Research II, 48, 1507-1528, 2001.

Bates, N. R.: Interannual variability of the oceanic $\mathrm{CO}_{2}$ sink in the subtropical gyre of the North Atlantic Ocean over the last two decades, J. Geophys. Res.-Oceans, 112, C09013, doi:10.1029/2006JC003759, 2007.

Bates, N. R.: Multi-decadal uptake of carbon dioxide into subtropical mode water of the North Atlantic Ocean, Biogeosciences Discuss., 8, 12451-12476, doi:10.5194/bgd-8-12451-2011, 2011.

Bates, N. R. and Peters, A. J.: The contribution of atmospheric acid deposition to ocean acidification in the subtropical North Atlantic Ocean, Mar. Chem., 107, 547-558, 2007.

Bates, N. R., Michaels, A. F., and Knap, A. H.: Seasonal and interannual variability of oceanic carbon dioxide species at the US JGOFS Bermuda Atlantic Time-series Study (BATS) site, DeepSea Res. II, 43, 347-383, doi:10.1016/0967-0645(95)00093-3, Corrigendum: 43, 1435-1435, 1996a.

Bates, N. R., Michaels, A. F., and Knap, A. H.: Alkalinity changes in the Sargasso Sea: Geochemical evidence of calcification? MAR CHEM, 51, 347-358, doi:10.1016/0304-4203(95)00068-2, 1996b.

Bates, N. R., Takahashi, T., Chipman, D. W., and Knap, A. H.: Variability of $p \mathrm{CO}_{2}$ on diel to seasonal timescales in the Sargasso Sea near Bermuda, J. Geophys. Res., 103, 15,567-15,585, doi:10.1029/98JC00247, 1998.

Bates, N. R., Pequignet, C. A., Johnson, R. J., and Gruber, N.: A short-term sink for atmospheric $\mathrm{CO}_{2}$ in subtropical mode water of the North Atlantic Ocean, Nature, 420, 489-493, doi:10.1038/nature01253, 2002.

Brewer, P. G., Sarmiento, J. L., and Smethie, W. M.: The Transient Tracers in the Ocean (TTO) program- The North Atlantic Study, 1981- The Tropical Atlantic Study, 1983, J. Geophys. Res.Oceans, 90, 6903-6905, doi:10.1029/JC090iC04p06903, 1985.

Brix, H., Gruber, N., and Keeling, C. D.: Interannual variability of the upper carbon cycle at station ALOHA near Hawaii, Global Biogeochem. Cy., 18, GB4019, doi:10.1029/2004GB002245, 2004.

Brown, P. J., Bakker, D. C. E., Schuster, U., and Watson, A. J.: Anthropogenic carbon accumulation in the subtropical North Atlantic, J. Geophys. Res., 115, C04016, doi:10.1029/2008JC005043, 2010.
Byrne, R. H., Mecking, S., Feely, R. A., and Liu, X. W.: Direct observations of basin-wide acidification of the North Pacific Ocean, Geophys. Res. Lett., 37, L02601, doi:10.1029/2009GL040999, 2010.

Caldeira, K. and Wickett, M. E.: Anthropogenic carbon and ocean $p \mathrm{H}$, Nature, 425, 365-368, 2003.

Caldeira, K. and Wickett, M. E.: Ocean model predictions of chemistry changes from carbon dioxide emissions to the atmosphere and ocean, J. Geophys. Res. Ocean, 110, (C9), C09S04, doi:10.1029/2004JC002671, 2005.

Dickey, T. D., Bates, N., Byrne, R. H., Chang, G., Chavez, F. P., Feely, R. H., Hansen, A., Karl, D., Moore, C., Wanninkhof, R., and Sabine C. L.: The NOPP O-SCOPE and MOSEAN Projects: Advanced sensing for ocean observing systems, Oceanography, 22, 168-181, 2009.

Dickson, A. G.: Thermodynamics of the dissociation of boric acid in synthetic seawater from 273.15 to $318.15 \mathrm{~K}$, Deep-Sea Res. Pt. I, 37, 755-766, 1990.

Dickson, A. G. and Millero, F. J.: A Comparison of the Equilibrium Constants for the dissociation of carbonic acid in seawater media, Deep-Sea Res. Pt. I, 34, 1733-1743, 1987.

Dickson, A. G., Sabine, C. L., and Christian, J. R.: Guide to best practices for ocean $\mathrm{CO}_{2}$ measurements, Sidney, British Columbia, North Pacific Marine Science Organization, PICES Special Publication 3, 2007.

Doney, S. C., Fabry, V. J., Feely, R. A., and Kleypas, J. A.: Ocean acidification: the other $\mathrm{CO}_{2}$ problem, Ann. Rev. Mar. Sci., 1, 169-192, doi:10.1146/annurev.marine.010908.163834, 2009.

Dore, J. E., Lukas, R., Sadler, D. W., and Karl, D. M.: Climatedriven changes to the atmospheric $\mathrm{CO}_{2}$ sink in the subtropical North Pacific Ocean, Nature, 424, 754-757, 2003.

Dore, J. E., Lukas, R., Sadler, D. W., Church, M. J., and Karl, D. M.: Physical and biogeochemical modulation of ocean acidification in the central North Pacific, P. Natl. A Sci., 106, 12235-12240, doi:10.1073/pnas.0906044106, 2009.

Fabry, V. J., Seibel, B. A., Feely, R. A., and Orr, J. C.: Impacts of ocean acidification on marine fauna and ecosystem processes, ICES J. Mar. Sci., 65, doi:10.1093/icesjms/fsn048, 414-432, 2008.

Feely, R. A., Doney, S. C., and Cooley, S. R.: Ocean acidification: Present and future changes in a high- $\mathrm{CO}_{2}$ world, Oceanography, 22, 36-47, 2009.

Friedlingstein, P., Houghton, R. A., Marland, G., Hackler, J., Boden, T. A., Conway, T. J., Canadell, J. G., Raupach, M. R., Ciais, P., and Le Quere, C.: Update on $\mathrm{CO}_{2}$ emissions, Nat. Geosci., 3, 811-812, 2010.

Friis, K., Körtzinger, A., Pätsch, J., and Wallace, D. W. R.: On the temporal increase of anthropogenic $\mathrm{CO}_{2}$ in the subpolar North Atlantic, Deep-Sea Res. I, 52, 681-98, 2005.

González-Dávila, M., Santana-Casiano, J. M., Rueda, M. J., and Llinás, O.: The water column distribution of carbonate system variables at the ESTOC site from 1995 to 2004, Biogeosciences, 7, 3067-3081, doi:10.5194/bg-7-3067-2010, 2010.

Grist, J. P., Josey, S. A., March, R., Good, S. A., Coward, A. C., de Cuevas, B. A., Alderson, S. G., New, A. L., and Madec, G.: The roles of surface heat flux and ocean heat transport convergence in determining Atlantic Ocean temperature variability, Ocean Dynam., 60, 771-790, doi:10.1007/s10236-010-0292-4, 2010. 
Gruber, N., Bates, N. R., and Keeling, C. D.: Interannual variability in the North Atlantic Ocean carbon sink, Science, 298, 23742378, doi:10.1126/science.1077077, 2002.

Houghton, R. A.: Carbon flux to the atmosphere from land-use changes: 1850-2005, in: TRENDS: A Compendium of Data on Global Change. Carbon Dioxide Information Analysis Center, Oak Ridge National Laboratory, U.S. Department of Energy, Oak Ridge, Tennessee, USA, 2008.

Hurrell, J. W. and Deser, C.: North Atlantic climate variability: The role of the North Atlantic, J. Marine Syst., 79, 231-244, doi:10.1016/j.jmarsys.2009.11.002, 2010.

Johnson, K. M., Wills, K. D., Butler, D. B., Johnson, W. K., and Wong, C. S.: Coulometric total carbon dioxide analysis for marine studies: maximizing the performance of an automated gas extraction system and coulometric detector, Mar. Chem., 44, 167-188, 1993.

Joyce, T. M., Pickart, R. S., and Millard, R. C.: Long-term hydrographic changes at 52 and 66 degrees W in the North Atlantic subtropical gyre and Caribbean, Deep-Sea Res. II, 46, 245-278, doi:10.1016/S0967-0645(98)00102-7, 1999.

Le Quéré, C., Raupach, M. R., Canadell, J. G., Marland, G., Bopp, L., Ciais, P., Conway, T. J., Doney, S. C., Feely, R. A., Foster, P., Friedlingstein, P., Gurney, K., Houghton, R. A., House, J. L., Huntingford, C., Levy, P. E., Lomas, M. R., Majkut, J., Metzl, N., Ometto, J. P., Peters, G. P., Prentice, I. C., Randerson, J. T., Runnning, S. W., Sarmeinto, J. L., Schuster, U., Sitch, S., Takahashi, T., Viovy, N., van der Werf, G. R., and Woodward, F. I.: Trends in the sources and sinks of carbon dioxide, Nat. Geosci., 2, 831-836, 2009.

Le Quéré, C., Takahashi, T., Buitenhuis, E. T., Rödenbeck, C., and Sutherland, S. C.: Impact of climate change and variability on the global oceanic sink of $\mathrm{CO}_{2}$, Global Biogeochem. Cy., 24, GB4007, doi:10.1016/0012-821X(72)90242-7, 2010.

Keeling, C. D.: Surface ocean $\mathrm{CO}_{2}$, in: Global Carbon Cycle, edited by: Heimann, M., Kluwer Publishers, 22-29, 1993.

Khatiwala, S., Primeau, F., and Hall, T.: Reconstruction of the history of anthropogenic $\mathrm{CO}_{2}$ concentrations in the ocean, Nature, 462, 346-349, 2009.

Kroopnick, P., Weiss, R. F., and Craig, H.: Total $\mathrm{CO}_{2}$, C-13 and dissolved oxygen at GEOSECS I in North Atlantic, Earth Planet. Sc. Lett., 16, 103-127, doi:10:1016/0012-821X(72)90244-0, 1972.

McKinley, G. A., Fay, A. R., Takahashi, T., and Metzl, N.: Convergence of atmospheric and North Atlantic carbon dioxide trends on multidecadal timescales, Nat. Geosci., 4, 606-610, doi:10.1038/ngeo1193, 2011.

Mehrbach, C., Culberson, C. H., Hawley, J. E., and Pytkowicz, R. M.: Measurement of the apparent dissociation constants of carbonic acid in seawater at atmospheric pressure, Limnol. Oceanogr., 18, 897-907, 1973.

Michaels, A. F. and Knap, A. H.: Overview of the US JGOFS Bermuda Atlantic Time-series Study and the Hydrostation S program, Deep-Sea Res. Pt. II, 43, 157-198, 1996.

Olafsson, J., Olafsdorrie, S. R., Benoit-Cattin, A., Arnarson, T. S., and Takahashi, T.: Rate of Iceland Sea acidification from time series measurements, Biogeosciences, 6, 2661-2668, 2010.

Orr, J. C., Fabry, V. J., Aumont, O., Bopp, L., Doney, S. C., Feely, R. A., Gnanadesikan, A., Gruber, N., Ishida, A., Joos, F., Key, R. M., Lindsay, K., Maier-Reimer, E., Matear, R., Monfray, P., Mouchet, A., Najjar, R. G., Plattner, G.-K., Rodgers, K. B., Sabine, C. L,
Sarmiento, J. L., Schlitzer, R., Slater, R. D., Totterdell, I., Weirig, M.-F., Yamanaka, Y., and Yool, A.: Anthropogenic ocean acidification over the twenty-first century and its impacts on calcifying organisms, Nature, 437, 681-686, 2005.

Robbins, L. L., Hansen, M. E., Kleypas, J. A., and Meylan, S. C.: $\mathrm{CO}_{2}$ calc: a user-friendly seawater carbon calculator for Windows, Max OS X, and iOS (iPhone), U.S. Geological Survey Open-File Report, 2010-1280, 1-17, http://pubs.usgs.gov/ of/2010/1280/, last access date: 15 December 2011, 2010.

Sabine, C. L., Feely, R. A., Gruber, N., Key, R. M., Lee, K., Bullister, J. L., Wanninkhof, R., Wong, C. S., Wallace, D. W. R., Tilbrook, B., Millero, F. J., Peng, T.-H., Kozyr, A., Ono, T., and Rios, A. F.: The oceanic sink for anthropogenic $\mathrm{CO}_{2}$, Science, 305, 367-371, 2004.

Santana-Casiano, J. M., Gonzalez-Davila, M., Rueda, M.-J., Llinas, O., and Gonzalez-Davila, E.-F.: The interannual variability of oceanic $\mathrm{CO}_{2}$ parameters in the western Atlantic subtropical gyre at the ESTOC site, Global Biogeochem. Cy., 21, GB1015, doi:10.1029/2006GB002788, 2007.

Schuster, U. and Watson, A. J.: A variable and decreasing sink for atmospheric $\mathrm{CO}_{2}$ in the North Atlantic, J. Geophys. Res., 112, C11006, doi:10.1029/2006JC003941, 2007.

Schuster, U., Watson, A. J., Bates, N. R., Corbiere, A., GonzalezDavila, M., Metzl, N., Pierrot, D., and Santana-Casiano, M.: Trends in North Atlantic sea-surface $\mathrm{fCO}_{2}$ from 1990 to 2006, Deep-Sea Res. II, 56, 620-629, doi:10.1016/j.dsr2.2008.12.011, 2009.

Steinberg, D. K., Carlson, C. A., Bates, N. R., Johnson, R. J., Michaels, A. F., and Knap, A. H.: Overview of the US JGOFS Bermuda Atlantic Time-series Study (BATS): a decade-scale look at ocean biology and biogeochemistry, Deep-Sea Res. II, 48, 1405-1447, 2001.

Takahashi, T., Sutherland, S. G., Sweeney, C., Poisson, A. P., Metzl, N., Tilbrook, B., Bates, N. R., Wanninkhof, R. H., Feely, R. A., Sabine, C. L., and Olafsson, J.: Biological and temperature effects on seasonal changes of $p \mathrm{CO}_{2}$ in global ocean surface waters, Deep-Sea Res. II, 49, 1601-1622, 2002.

Takahashi, T., Sutherland, S. C., Wanninkhof, R., Sweeney, C., Feely, R. A., Chipman, D. W., Hales, B., Friederich, G. E., Chavez, F. P., Watson, A. J., Bakker, D. C. E., Schuster, U., Metzl, N., Yoshikawa-Inoue, H., Olafsson, J., Arnarson, T. S., Tilbrook, B., Johannessen, T., Olsen, A., Bellerby, R. J., de Baar, H. J. W., Nojiri, Y., Wong, C. S., Delille, B., and Bates, N. R.: Climatological mean and decadal change in surface ocean $p \mathrm{CO}_{2}$, and net sea-air $\mathrm{CO}_{2}$ flux over the global oceans, Deep-Sea Res. II, 56, 554-577, doi:10.1016/j.dsr2.2008.12.009, 2009.

Tanhua, T. and Wallace, D. W. R.: Consistency of TTO-NAS Inorganic Carbon Data with modern measurements, Geophys. Res. Lett., 32, L14618, doi:10.1029/2005GL023248, 2005.

Thomas, H., Schiettecatte, L. S., Suykens, K., Kone, Y. J. M., Shadwichk, E. H., Prowe, A. E. F., Bozec, Y., de Baar, H. J. W., and Borges, A. V.: Rapid decline of the $\mathrm{CO}_{2}$ buffering capacity in the North Sea and implications for the North Atlantic Ocean, Global Biogeochem. Cy., 21, GB4001, doi:10.1029/2006GB002825, 2007.

Wanninkhof, R., Doney, S. C., Bullister, J. L., Levine, N. M., Warner, M., and Gruber, N.: Detecting anthropogenic $\mathrm{CO}_{2}$ changes in the interior Atlantic Ocean between 1989 and 2005, J. Geophys. Res., 115, C11028, 2010. 
Watson, A. J., Schuster, U., Bakker, D. C. E., Bates, N. R., Corbiere, A., Gonzalez-Davila, M., Friedrich, T., Hauck, J., Heinze, C., Johannessen, T., Körtzinger, A., Metzl, N., Olafsson, J., Olsen, A., Oschlies, A., Padin, X. A., Pfiel, B., Santana-Casiano, M., Steinhoff, T., Telszewski, M., Rios, A. F., Wallace, D. W. R., and Wanninkhof, R.: Accurately tracking the variation in the North Atlantic sink for atmospheric $\mathrm{CO}_{2}$, Science, 326, 1391-1393, doi:10.1126/science.1177394, 2009.
Zhang, L. P., Wu, L. X., and Zhang, J. X.: Freshwater loss/salinification: Simulated response to recent freshwater flux change over the Gulf Stream and it's extension: Coupled oceanatmosphere adjustment and Atlantic-Pacific teleconnection, J. Climate, 24, 3971-3988, doi:10.1175/2011JCLI4020.1, 2011. 